\title{
ENVIRONMENTAL LOBBY EFFECTIVENESS - THE CASE OF LITHUANIA AND THE UNITED KINGDOM
}

\author{
Luka Vavtar \\ University of Ljubljana, Faculty of Administration, \\ Gosarjeva ulica 5, 1000 Ljubljana, Slovenia \\ E-mail: luka.vavtar@gmail.com
}

Received on 14 February 2014; accepted on 10 June 2014

doi:10.13165/SMS-14-6-2-05

Abstract. In the last decades, the world has been facing important and rapid changes of global climate and other aspects of environment. In response to this, countries are adopting climate change laws and other environmental regulations, which are causing huge social tensions and involvement of lobby groups. Lithuanian environmental interest groups are increasingly influenced by Europeanization and a parallel process of institutionalization. Interestingly, Lithuania already accepted a Law on Lobbying Activities in 2000 and became a pioneer in Europe. The UK case is significant, because they have introduced the Climate Change Act 2008 and, due to high pressure from different interest groups, ENGOs and corporate sector. The aim of the article is to examine the main factors and determinants that influence legal environmental regulation as a consequence of lobbying in Lithuania and the UK. The analysis examines lobby effectiveness as the difference among interests groups policy preferences (before lobbying), proposed policy (after lobbying) and the general outcome of prominent cases. The results indicate that the ability of groups to influence decision making process varies with the policy issues.

Keywords: environmental lobbying, Europeanization, institutionalization, regulation, Lithuania, UK.

JEL classification: Q56, Q54, D72.

Socialinių mokslų studijos / Societal Studies

(C) Mykolo Romerio universitetas, 2014

(C) Mykolas Romeris University, 2014
ISSN 2029-2244 (online)

http://www.mruni.eu/lt/mokslo_darbai/SMS/

http://www.mruni.eu/en/mokslo_darbai/SMS/ 


\section{Introduction}

Lobbying is regarded as the action to influence policy makers. It includes activities that influence legislative decisions by actions that work in order to establish grounds for legitimate interest in the legislative process, and that this interest will be taken into consideration. According to Marusca and Irimies", "It represents a form of maturity of any democracy, as it allows people to influence, through its low-profile, informal representatives, the decisions of official, formal, elected representatives". Lobby groups and front groups can be regarded as holistic and strategic attempts used by industry to put into force influence on both, the formal and public, agendas and reduce outrage over delayed policy action by government ${ }^{2}$.

Lobby effectiveness depends on different determinants that can be separated into two main groups - external and internal factors. External factors are the following ones: 1) the opinion of the target of lobbying on a certain issue, 2) the direction and intensity of competition, and 3) the support of mass media and citizens. On the other hand, internal (organizational) factors include the following ones: 1) the amount and quality of resources available for lobbying, 2) the effectiveness of planning, and 3) uniformity of support among constituent publics. Both external and internal situational factors contribute essentially to the success of lobbying activities. Contradictions decrease credibility, inefficiency reduces flexibility of lobbying action ${ }^{3}$.

In some countries, there have been introduced special laws to stipulate lobbying activities. Lithuania accepted law on lobbying activities in the year 2000 and became a pioneer in Europe in this field. As a consequence, lobbyists have to register and reveal their clients, lobbied issues and revenues ${ }^{4}$.At EU level, the European Commission in 2008 launched an Online Register of lobbyists. The latter was merged into the joint Transparency Register in 2011, together with the European Parliament register ${ }^{5}$. In the case of the UK, lobbying is currently self-regulated by the Public Affairs Council' ${ }^{6}$. There are many groups associated with environmental lobbying in the UK. Their activities became a core issue in the public discourse, especially during the process of preparing and introducing the Climate Change Act 2008. Through the adoption of this law, the UK became one of the first countries in the world that has (strict)

1 Marusca, L.; Irimies, C. 2013. Models of Lobby in Europe. Journal of Media Research. 1(15): $56-62$.

2 Hodder, P. 2009-2010. Lobby Groups and Front Groups: Industry Tactics in the Climate Change Debate. Melbourne Journal of Politics. 34: 45-81.

3 Jaatinen, M. 1998. Lobbying for Conflict Accommodation - A Contingency Model. Corporate Communications: An International Journal. 3(1): 23-42. Regulatory Regimes. Riga: Providus.

$5 \quad$ Ibid.

6 Marusca, L.; Irimies, C., supra note 1. 
legal grounds for climate change prevention and adaptation ${ }^{7}$.The main lobbying groups (in the non-governmental sector) associated with environment in the UK are the following ones: Greenpeace UK, Friends of the Earth UK, World Wildlife Fund UK, British Ecological Society, etc. The most influential groups in the corporate sector (mostly oil corporations) in the UK include companies, such as the following ones: British Petroleum, BG Group, Expro and Tullow Oil. The most prominent NGOs in the field of environment in Lithuania are the following ones: Friends of the Earth Lithuania - Lithuanian Green Movement, Coalition of Lithuania ENGOs (environmental NGOs) consists of BEF Lithuania (Baltic Environmental Forum Group - coordinator of coalition), Community Atgaja, Lithuania Ornithological Society, Environmental Centre for Administration and Technology (ECAT Lietuva), Lithuanian fund for nature, Environmental information centre and Water home (Global water partnership). There is a distinctive difference on lobbying operating methods between non-governmental and corporate organizations. They have different goals, methods, strategies, tactics and resources. Hereinafter, some of these groups and their strategies will be analysed, also its effectiveness on general level will be assessed according to A Guide to Effective Lobbying in Europe ${ }^{8}$.

The purpose of the analysis is to measure what are the objectives and content of interest groups policy preferences (before lobbying) in comparison to the policy proposals (after lobbying). Compliance of the objectives is determined on the basis of ex ante and ex post lobbying comparison. In this way, "winners and losers" of the policy making process will be identified. The general outcome is important, because policy goal may not be reflected in the result of the lobbyism. It is important to be aware of the limitation that a change in the policy content may not be a consequence of lobbying activities of a particular interest group (non-governmental or corporate). However, this method can still help to determine which groups were successful enough to shift the primary policy goals to be consistent with their priorities. The objectives of this paper are to analyse environmental lobbying in Lithuania and the UK on the basis of Šilutè-Taurage Chevron shale gas, Visaginas Nuclear Power Plant, Lancashire shale gas and, consequently, to show the main factors that help to investigate its effectiveness. As for the research methods, there are compilation method and comparative analysis of scientific and other literature. The paper is organised as follows: 1) it describes the main features of environmental lobbying and preconditions for its effectiveness; 2) presents an overview of the Lithuanian and the UK cases with analyses and findings; 3) delivers an insight into ENGOs environmental lobbying strategies; 4) describes corporate environmental lobbying strategies; and finally, the paper concludes with a list of references.

7 Lockwood, M. 2013. The Political Sustainability of Climate Policy: The Case of the UK Climate Change Act. Global Environmental Change. 23(5): 1339-1348. New York City: Burson Marsteller, 2013 [accessed on 2013-10-29]. <http://lobbyingsurvey. burson-marsteller.eu/>. 


\section{Environmental lobbying and its effectiveness}

According to Thomas ${ }^{9}$, it is essential to distinguish non-governmental and corporate lobbying when addressing environment. There is a generic definition of NGOs, especially applied for Western Europe and the EU. NGOs are considered as a wide range of groups that focus on what can loosely be defined as broad public concern, including the environment. In comparison to other interest groups, the non-governmental sector is generally more public oriented. On the other hand, the corporate sector is focused on specific issues and interests of specific businesses. The corporate sector is not always associated with only some cluster of interests. Thomas ${ }^{10}$ states that "business is no monolith either, even though it is often referred as such, united in every attitude, in political purpose and in its reactions to challenges to its place in society. "Business reactions cannot be regarded in a general way (such as ENGOs). There is no general business attitude to environmental protection, due to different economic interests ${ }^{11}$.

Environmental degradation occurs when all participating agents do not fully assess the costs of their use. In this field, ENGOs (NGOs that focus on environmental protection) have no authority needed to prevent such situations or to hinder individual or corporate harmful actions. Usually, the reason is in a lack of financial resources to establish grounds for that. Nonetheless, in many cases ENGOs can have a significant, indirect influence and impact on environmental policies ${ }^{12}$. ENGOs achieve their lobbying goals by pressuring policy-makers. Stigler ${ }^{13}$ posits that there is a presumption when the legislator likes to maximize a political support, by giving some amount of acknowledgement to interest groups and ENGOs, which is also in public interest.

One of the biggest successes of ENGOs lobbying is the adoption of the Aarhus convention in 1998. This document was the first international legally binding convention that stimulates democracy in terms of participation. On the grounds of historical facts, the participants realized that projects and activities with public support are fastest and most effective implemented. The incentive to adopt this document came from ENGOs, the first time in history they gained a partner status in the process of shaping the convention. They have also participated in the council in the form of international coalition of ENGOs. The Aarhus convention ensures

9 Thomas, C. Nongovernmental Organizations as a Lobbying Force in the European Union: Myths and Realities [interactive]. Juneau: University of Alaska, 1999 [accessed on 2013-08-25]. $<$ http://aei.pitt.edu/2402/1/002903_1.PDF>.

10 Ibid.

11 Thomas, C., supra note 9.

12 Binder, S.; Neumayer, E. 2005. Environmental Pressure Group Strength and Air Pollution: An Empirical Analysis. Ecological Economies. 55(4): 527-538.

13 Stigler, G.J. 1971. The Theory of Economic Regulation. Bell Journal of Economics and Management Science. 2(1): 3-21. 
public access to the environmental data, especially in the fields of the following: 1) access to the environment data in general, 2) cooperation in the process of accepting environmental acts, and 3) judicial protection in this area ${ }^{14}$.

According to the Guide to Effective Lobbying in Europe, important things for effective lobbying include the following ones ${ }^{15}$ :

1. Transparency about your interest (it is usually a precondition for a discussion),

2. Being part of the process (the easiest way to influence and follow the legislative process),

3. Understanding the legislative process and its technicalities (helps to deliver the right arguments at the right time),

4. Thinking politically (considering the values of a political argument),

5. Identifying ultimate audience and clearing the set of objectives (importance of being prepared to adapt the strategy and response),

6. Knowing a wide range of people (target them at the right time),

7. Mobilising people to act (looking for allies and coalitions; even ad hoc cooperation can be as effective as long standing partnerships),

8. Using relevant channels of communications (digital age for digital lobbying),

9. Being creative and memorable (essential in order to succeed).

Effective environmental lobbying into politics should improve environmental quality $^{16}$. One of the reasons why lobbying is not effective, due to the lack of lobbying regulations, has been the uncertainty and contradictory view about what it is or should be capable of achieving ${ }^{17}$. In the real world, there is some difficulty in implementing optimal policy, because it is determined by (usually complicated) political process, and the policy preferences are different between youngand old generations ${ }^{18}$.

\section{The case of Lithuania and the UK}

Lithuania is especially significant due to historical reasons, where some ENGOs,such as LGM (Lithuania Green Movement), cooperated in the democratization process and in raising public awareness and participation on environmental issues. After entering the EU, another process played a significant role, the Europeanization.

14 Garçon, G. 2013. The Rights of Access to Justice in Environmental Matters in the EU - The Third Pillar of the Aarhus Convention.European Food \& Feed Law Review. 8(2): 78-90.

15 A Guide to Effective Lobbying in Europe 2009 [interactive]. New York City: Burson Marsteller, 2009 [accessed on 2013-08-27]. <http://www.burson-marsteller.com/bm-blog/bursonmarstellers-guide-to-effective-lobbying-in-europe-2009/>.

16 Ono, T. 2009. The Political Economy of Environmental and Social Security Policies: The Role of Environmental Lobbying. Economics of Governance. 10(3): 261-296.

17 Kalniņš, V., supra note 4.

18 Ono, T. 2009., supra note 16. 
Lithuanian environmental lobbying was greatly affected by this process ${ }^{19}$. Even though the principle of subsidiarity is widely recognized, certain environmental policies and standards can be better addressed and implemented on the EU level. Setting a unified and Union-wide system of product standards is a good example how health, safety and environmental standards can be achieved. This sort of system contributes to the facilitation of the free movement of goods and services across the EU. Europeanization is also expressed in binding directives and other Union legislations. This is another reason why national interest groups are trying to spread the extent of their supranational activities ${ }^{20}$. Some organizations were (and still are) even mostly dependant on EU funding and, as a consequence, on support biased proEuropean. Europeanization is reflected in the amount of cooperation that member states interest groups are willing to have with Brussels as the EU lobbying centre to reach their goals. Nevertheless, financial reasons are not always the reason why some interests are more represented, e.g., influence of large business companies. Interest groups do not turn over their competences and activities to the European level, but they participate in the European environmental associations (e.g., Lithuanian Wind Power Association or Atgaja regards itself represented through the European Wind Energy Association), they monitor the policy making process and are in touch with the EU institutions (e.g., ENGO Atgaja was invited to the round table discussion held under the Directorate General Environment, although there was no guarantee that their positions would be reflected in the policies). On the other hand, corporate and non-corporate lobbying should take into consideration the relations with the domestic government, also known as a process of institutionalization. The latter is often referred to as parallel process of the Europeanization, because the relation with domestic governmental institutions can be a precondition for their EU level influence. Lithuanian ENGOs are better and unified represented by Lithuanian ENGOs Coalition that was established in 2005. The Coalition also encourages a higher level of cooperation and information exchange. These are all characteristics of institutionalization by presenting (unite) positions on certain policies to the governmental bodies, which later on leads to a better implementation process ${ }^{21}$.

The UK is listed as a reference in lobbying activity. This is because lobbying has an important role in the legislative process. The process is carried out through a permanent exchange of information. There are some distinctive terms associated with this, such as public relations, public affairs, political consulting and corporate affairs $^{22}$. In general, the system ensures that almost anyone can lobby an MP or

19 Mazylyte, L.; Povilaitis, R. 2011. Interest Representation at the European Union Level: The Case of Lithuanian Environmental Interest Groups. 7th Annual International Scientific Conference: New Dimensions in the Development of Society. Jelgava: Latvia University of Agriculture, p. 50-56.

20 Oates, W. E.; Portney, P. R. The Political Economy of Environmental Policy. 2003. Handbook of Environmental Economics. Amsterdam: Elsevier, p. 325-354.

21 Mazylyte, L.; Povilaitis, R., supra note 19.

22 Marusca, L.; Irimies, C., supra note 1. 
Lord in the UK. Some examples are the following: individual member of the public, groups of constituents, local businesses, organised pressure groups/campaigners, commercial organisations ${ }^{23}$.

The UK is recognized because of high environmental lobbying during the process of accepting the climate change law. However, it is not the only legislative source for climate change in the UK; the Climate Change Act 2008 definitely is the most important at present. Interestingly, Scotland has separate legislation in this area, which proves how complex are climate issue questions among governments. There were tax measures included (especially for large energy users ${ }^{24}$ ) and provisions on encouraging renewable electricity. These two examples reflect the environmental lobbying effect ${ }^{25}$.The UK became the first country in the world with long run legally binding regulation on climate change. Until 2050, all six in Kyoto protocol defined greenhouse gasses (carbon dioxide, methane, nitrous oxide, hydrofluorocarbons, perfluorocarbons and sulphur hexafluoride) have to decrease at least by $80 \%$ in comparison to the base year 1990. The aim is to establish a country with low base economy. Ministries have competences to introduce measures that would stimulate the implementation process. There is also a special body (Committee on Climate Change) that is helping with the implementation ${ }^{26}$.

Table 1 shows the analysis of environmental lobbyism in terms of objectives compliance (difference between preferences among participators and the following outcome) and effectiveness. There are two case studies in Lithuania and one in the UK. Šiluté-Tauragè Chevron shale case is significant, because the outcome was that Chevron retreated from a tender for a license to explore hydrocarbon resources (e.g., shale gas). Of course, there were many different influences included, but ENGOs and other (local) interest groups resistance definitely contributed to this result. The main reason why Lithuania accepted Chevron's bid in the first place is their dependency on a single energy source, the Russian company Gazprom. ENGOs (Coalition) agreed that the technology in shale gas exploration is unreliable and consequently represents a risk to contaminate ground water resources. The Coalition also opposed the project due to publicly unrepresented expert evaluated effects. Chevron's opinion was different, they spoke in favour of economic potential for the region and expressed concerns because of changes in legislation and newly adopted acts. They also mentioned an unstable political environment in the state and that the investment is not reasonable if they do not know what regulation to expect. Important factors were definitely proposals for 40 percent tax rate on income

23 Lobbying [interactive]. London: The Parliament of the United Kingdom of Great Britain and Northern Ireland, 2013 [accessed on 2013-08-25]. <http://www.parliament.uk/get-involved/ have-your-say/lobbying/>.

24 Lockwood, M., supra note 7.

25 Reid, C. T. 2013. Climate Law in the United Kingdom. Jus Gentium: Comparative Perspectives on Law and Justice. Dordrecht: Springer, p. 537-549. 
from shale-hydrocarbon production and a legal demand to get a local government approval for an environment impact before exploration. The latter was more or less a consequence of the local communities' opposition to the Chevron's project. Local interest groups lobbying effectiveness can be assessed as very successful, because one of the results was prior mentioned obligatory local consent. Last but not least, Chevron retreated from the tender, so their corporate lobbying can be assessed as less successful, which is also a consequence of negative information spread in the media in connection with certain Chevron's incidents (e.g., rejected shale gas fracking in France). Lithuania has closed its last nuclear reactor, Ignalina nuclear power plant, in 2009 (INPP). The latter was generating around 70 percent of the country's electricity. Until this moment, electricity was a major export good, but since 2009, there has been around 80 percent import energy dependence on Russia. As an alternative, Lithuania decided to build a new plant with cooperation of Japanese company GE Hitachi (they lobbied for higher project ownership), Visaginas nuclear power plant (VNPP). After a turn down of this project on 2012 non-binding referendum, there has been a lot of uncertainty around this project. A final decision is anticipated to be made in 2014, since new consultations started in 2013 with regional partners Latvia and Estonia (they lost some interest in the project due to unpleasant economic times). It can be seen that ENGOs policy preferences supported with VNPP negative consequences potentially caused (pollution by uranium mining, radioactive waste and possibility of accidents) were not in compliance with policy proposals. Still, their lobbyism can be assessed as successful, since the project was turned down on referendum and was not carried on by development yet (although they had some help from the financial crisis). Lancashire shale gas fracking sites in the UK are important, because national policy on shale gas is in favour of fracking in order to establish greater energy security, growth and jobs. The government posits that they are encouraging safe and environmentally sound exploration to determine this potential. On the other hand, ENGOs (Friends of the Earth, Greenpeace, etc.) and local anti-fracking groups warn about unexplored consequences, possible quakes and water pollution. Experts say that fracking will do little to tackle climate change. The company in charge for fracking is Cuadrilla Resources, the only business to have used modern hydraulic fracturing technology on British soil. Cuadrilla arguments that extensive geological analysis has been made and local communities could prosper from the project. Their lobbyism can be assessed as more or less effective due to their recent announcement to apply for planning permissions to drill eight wells and test shale gas flows. Although the public support had fallen, the national policy proposal had not changed. ENGOs were partly successful in influencing the public polling, but unsuccessful when assessing the outcome due to the continuation of the fracking projects ${ }^{27}$.

27 Harvey, F.; Vaughan, A. CuadrillaAnnounces Two New Lancashire Fracking Sites [interactive]. London: The Guardian, 2014 [accessed on 2014-02-11]. <http://www.theguardian.com/ environment/2014/feb/04/cuadrilla-two-new-lancashire-fracking-sites-shale-gas>. 
Table 1. Analysis of environmental lobbyism - objectives compliance and effectiveness

\begin{tabular}{|c|c|c|c|c|}
\hline & \multicolumn{2}{|c|}{$\begin{array}{l}\text { Interest group policy prefer- } \\
\text { ence }\end{array}$} & \multirow{2}{*}{$\begin{array}{c}\text { Policy } \\
\text { (legislation) } \\
\text { proposal }\end{array}$} & \multirow[t]{2}{*}{ Outcome } \\
\hline & ENGOs & Corporate & & \\
\hline $\begin{array}{l}\text { Šilutè-Tauragè } \\
\text { Chevron shale } \\
\text { gas (LT) }\end{array}$ & $\begin{array}{l}\text { Unreliable } \\
\text { technology } \\
\text { is a risk to } \\
\text { contaminate } \\
\text { ground water }\end{array}$ & $\begin{array}{l}\text { Chevron } \\
\text { position } \\
\text {-economic } \\
\text { potential is } \\
\text { of primary } \\
\text { importance }\end{array}$ & $\begin{array}{l}\text { Tax rate ( } 40 \\
\%) \text { on income } \\
\text { from shale- } \\
\text { hydrocarbon } \\
\text { production; } \\
\text { obligatory local } \\
\text { government } \\
\text { approval }\end{array}$ & $\begin{array}{l}\text { Chevronretreated } \\
\text { from a tender for } \\
\text { a license to } \\
\text { explore hydro- } \\
\text { carbon resources } \\
\text { (shale gas) }\end{array}$ \\
\hline $\begin{array}{l}\text { Visaginas } \\
\text { Nuclear Power } \\
\text { Plant (LT) }\end{array}$ & $\begin{array}{l}\text { Pollution } \\
\text { by uranium } \\
\text { mining; } \\
\text { radioactive } \\
\text { waste; } \\
\text { possible } \\
\text { accidents }\end{array}$ & $\begin{array}{l}\text { Hitachi - } \\
\text { lobbying } \\
\text { for high } \\
\text { ownership } \\
\text { percentage }\end{array}$ & $\begin{array}{l}\text { New consulta- } \\
\text { tions with region- } \\
\text { al partners Latvia } \\
\text { and Estonia; the } \\
\text { final decision pre- } \\
\text { sumably in } 2014\end{array}$ & $\begin{array}{l}80 \% \text { of import } \\
\text { energy depen- } \\
\text { dence on Russia, } \\
\text { after a stop as a } \\
\text { consequence of } \\
\text { NPP turn down } \\
\text { on non-binding } \\
\text { referendum in } \\
2012\end{array}$ \\
\hline $\begin{array}{l}\text { Lancashire } \\
\text { shale gas (UK) }\end{array}$ & $\begin{array}{l}\text { Unexamined } \\
\text { consequences; } \\
\text { possible } \\
\text { quakes; water } \\
\text { pollution }\end{array}$ & $\begin{array}{l}\text { Cuadrilla } \\
\text {-extensive } \\
\text { geological } \\
\text { analysis have } \\
\text { been made }\end{array}$ & $\begin{array}{l}\text { Shale gas has the } \\
\text { potential to pro- } \\
\text { vide the UK with } \\
\text { greater energy } \\
\text { security, growth } \\
\text { and jobs }\end{array}$ & $\begin{array}{l}\text { Public support } \\
\text { for shale gas has } \\
\text { fallen; Cuadrilla } \\
\text { has announced } \\
\text { application for } \\
\text { new permissions } \\
\text { to drill }\end{array}$ \\
\hline
\end{tabular}

Source: Bradley; Pocius; Visaginas Nuclear Power Plant Project; Harvey and Vaughan; Jowit and Gersmann ${ }^{28}$

28 Bradley, B. Lithuania Considers Revising Shale-Gas Laws After Chevron Quits [interactive]. New York City: Bloomberg, 2013 [accessed on 2014-01-28]. <http://www.bloomberg.com/ news/2013-10-09/lithuania-considers-revising-shale-gas-laws-after-chevron-quits.html >.; Pocius, E. Chevron in Lithuania: The Environmental Perspective [interactive]. The Lithuania Tribune, 2012 [accessed on 2014-01-22]. <http://www.lithuaniatribune.com/18441/chevronin-lithuania-the-environmental-perspective-201218441/>; Visaginas Nuclear Power Plant Project [interactive]. Vilnius: Lietuvosenergija, UAB, 2014 [accessed on 2014-01-24]. <http:// www.vae.lt/en/pages/about-the-project>.; Harvey, F.; Vaughan, A. Cuadrilla Announces Two New Lancashire Fracking Sites [interactive]. London: The Guardian, 2014 [accessed on 2014-0211]. <http://www.theguardian.com/environment/2014/ feb/04/cuadrilla-two-new-lancashirefracking-sites-shale-gas >.; Jowit, J.; Gersmann, H. Fracking 'Probable'Cause of Lancashire Quakes [interactive]. London: The Guardian, 2011 [accessed on 2014-02-04]. <http://www. theguardian.com/environment/2011/nov/02/ fracking-cause-lancashire-quakes $>$. 
Table 2 illustrates the effectiveness of different organisations involved in lobbying in Lithuania and the UK. The research was carried out by a company - Burson Marsteller, according to the Guide for effective lobbying in Europe ${ }^{29}$. Percentages show respondents opinions about the particular organization and a more detailed effectiveness of their lobbying activities. The higher the percentage, the higher the effectiveness of the group of interest. Interestingly for the present case, the average percentages for the UK are relatively high in comparison to Lithuanian ones. In the $\mathrm{UK}$, the majority of the people who participated in the research defended that their organizations are effective in lobbying activities, especially trade associations and, maybe less expected, public affairs agencies (which is probably a consequence of legal regulation - sometimes they get an assured sit at a bargain table). In Lithuania, only trade associations got a percentage higher than 50 percent; on the other hand, trade unions were rated very low.

Table 2. Comparison of different types of organizations and their effectiveness in environmental lobbying

\begin{tabular}{|l|c|c|}
\hline Organization & Lithuania & UK \\
\hline Trade associations & $53 \%$ & $84 \%$ \\
\hline Professional organizations & $34 \%$ & $70 \%$ \\
\hline NGOs & $28 \%$ & $70 \%$ \\
\hline Companies & $47 \%$ & $63 \%$ \\
\hline Trade unions & $22 \%$ & $57 \%$ \\
\hline Public affairs agencies & $37 \%$ & $77 \%$ \\
\hline Embassies & $31 \%$ & $70 \%$ \\
\hline Journalists & $34 \%$ & $60 \%$ \\
\hline Think tanks & $25 \%$ & $60 \%$ \\
\hline Law firms & $25 \%$ & $64 \%$ \\
\hline Academics & $31 \%$ & $40 \%$ \\
\hline Citizens & $22 \%$ & $43 \%$ \\
\hline
\end{tabular}

Source: A Guide to Effective Lobbying in Europe ${ }^{30}$

29 A Guide to Effective Lobbying in Europe, supra note 8.

30 Ibid. 


\section{ENGOs environmental lobbying strategies}

According to Smith and Connelly ${ }^{31}$, there are ten different types of ENGOs lobbying and similar pressuring activities:

1. Informal, discreet lobbying;

2. Formal lobbying;

3. Collecting and sending letters or petitions from the public;

4. Producing scientific research and reports;

5. Taking legal action;

6. Organizing demonstrations and marches;

7. Staging media stunts;

8. Promoting consumer boycotts;

9. Engaging in non-violent direct action;

10. Engaging in violent direct action.

To the list above, there can be added campaign contributions or endorsements to environmentally friendly candidates ${ }^{32}$. ENGO's lobbying contributes to the environmental good if they get a potential political support. Environmental good is a public good (non-rivalry and non-excludable). It can also bring welfare gain from a particular policy. Exchange of information shapes the calculus of the political support function $^{33}$. It is important to take into consideration that none of the activities are guaranteed to resemble into policy success. Generally, the output of ENGOs is measured by the probability that the policy-maker will increase provisions of the environmental good. The feasibility that governments will increase provision of the public good depends on the strength of the ENGO community. The latter is derived from the number of members and the level of financial support ${ }^{34}$.

One of the most important questions is about the effectiveness of ENGOs environmental lobbying. Aidt ${ }^{35}$ defended that effectiveness depends on a competition among environmental and industry lobbies over accepting policies ${ }^{36}$. Fredriksson ${ }^{37}$ shown that balance or equilibrium of pollution tax is rising almost parallel with the environmental lobby group membership. Fredrikssonet al..$^{38}$, on the

31 Smith, G.; Connelly, J. 1999. Politics and the Environment. From Theory to Practice. London: Routledge.

32 Grossman, G.; Helpman, E. 2001. Special Interest Politics. Cambridge: MIT Press.

33 Binder, S.; Neumayer, E., supra note 12.

34 Ibid.

35 Aidt, T. S. 1998. Political internalization of economic externalities and environmental policy. Journal of Public Economics, 69: 1-16.

36 Binder, S.; Neumayer, E., supra note 12.

37 Fredriksson, Per G., et al. 2005. Environmentalism, Democracy and Pollution Control. Journal of Environmental Economics and Management. 49(2): 343-365. Fredriksson, Per G., et al., supra note 38. 
other hand, invented a formal model proving that ecology tax is increasing in the number of environmental lobby groups.

In order to measure ENGOs influence, a good tool was developed by Betsill and Corell and later on complemented by Rietig ${ }^{39}$, it is called a qualitative theoretical framework. The authors divided the amount of influence into three sections: low, modest and high. This framework was later on tested by several empirical studies ${ }^{40}$ of (international) environmental negotiations. The model differentiates influence linked to negotiation process and to the negotiation outcome. There are three essential indicators to assess the influence of ENGOs: 1) contribution to framing the issue of examination, 2) impact during agenda setting (did they manage to include or exclude topics), and 3) success in influencing the key positions ${ }^{41}$. The model can be easily adapted to the Lithuanian and the UK cases. Negotiations are lasting during the exchange of information in the legislative process, outcome is the final regulation.

A sign of ENGOs lobby effectiveness is the lack of protests. Lobbying can be in lots of cases much more effective than direct activities. People do not identify with climate change, because it is not directly connected with their daily life ${ }^{42}$.

Figure 1 shows the most important indicators to determine low, moderate or high influence of ENGOs lobbying. Timing is very important, because negotiations should begin as soon as possible. Person capabilities contribute to a better outcome, the more expert and established they are, the better. Policy and entrepreneurial strategies matter in terms of active engagements and creativity in ideas. The indicator insider represents how many seniors there are within delegation (e.g., in special meetings, conferences, etc.) and how powerful this delegation is. The amount of influence is reflected with the size of the diamond, the larger it is, the larger amount on negotiations it has.

39 Rietig, K. Public Pressure versus Lobbying - How Do Environmental NGOs Matter Most in Climate Negotiations? Centre for Climate Change Economics and Policy, Working Paper No. 79. Grantham Research Institute on Climate Change and the Environment, Working Paper No. 70 [interactive]. London, Leeds: Centre for Climate Change Economics and Policy; London: Grantham Research Institute on Climate Change and the Environment, 2011 [accessed on 2013-08-25]. <http://www2.lse.ac.uk/GranthamInstitute/ publications/WorkingPapers/ Papers/70-79/WP70_environmental-NGOS-climate.pdf $>$.

40 Andresen and Skodvin. 2008. Non-State Influence in the International Whaling Commission, 1970-2006; Betsill and Corell. 2008. InNGO Diplomacy: The Influence of Nongovernmental Organization in International Environmental Agreements; Betsill and Corell. 2001. NGO Influence in International Environmental Negotiations: A Framework for Analysis.

41 Rietig, K., supra note 40.

42 Rucht, D. 2001. Lobbying or Protest Strategies to Influence EU Environmental Policies. Contentious Europeans: Protest and Politics in an Integrating Europe. Lanham: Rowman\& Littlefield, p. 125-142. 


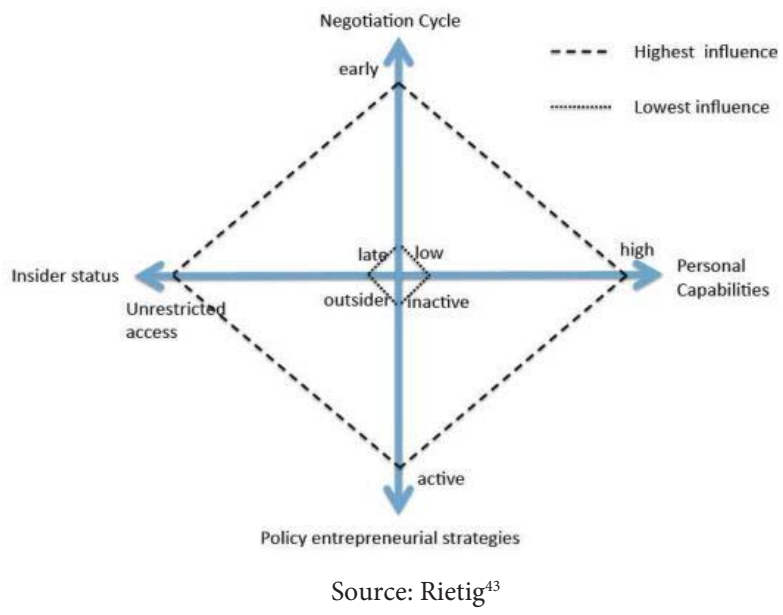

Figure 1. Indicators to determine low/modest/high ENGOs lobbying influence

One of the most influential forces among UK ENGOs is Greenpeace. Their main activities in the pressuring policy-makers field include promoting campaigns, producing and dissemination of reports, organising events with MPs (Members of Parliament) and submissions to consultations (also legal actions if appropriate). It is positive that they are very international oriented. In this way, they can also act outside of the national borders, e.g., in the EU arena and globally, including participations on important world treaties, conventions or conferences on environmental protection (e.g., the Earth Summit 2012 and the Aarhus convention). Another area of work is cooperation with businesses. They publish a quarterly business newsletter and develop showcases of positive sustainable solutions. Greenpeace is associated to illegal activities, such as blocking Downing Street as a way of exposing environmental crimes. They do not receive any funding from governments, corporations or political parties, but it has been several times criticised by many prominent people ${ }^{44}$. To consider Greenpeace as a factor on the lobbying arena is important mostly due to their style of operation. They are gaining front page publicity, often linked to confrontational matters, which is in accordance to their modus operandi. However, many views from the Greenpeace prism as an ENGO are often distorted, oversimplified and often unfairly negative $e^{45}$.

43 Rietig, K., supra note 40.

44 Gkotsis, I. I., et al. 2006. Lobbying for the Environment: The Case of Greenpeace. International Conference on Sustainable Management and Development of Mountainous and Island Areas. Naxos: University of Thrace, p. 114-121.

45 Thomas, C. Nongovernmental Organizations as a Lobbying Force in the European Union: Myths and Realities[interactive]. Juneau: University of Alaska, 1999 [accessed on 2013-08-25]. $<$ http://aei.pitt.edu/2402/1/002903_1.PDF>. 


\section{Corporate environmental lobbying strategies}

In connection to corporate climate change lobbying, there is often mentioned a conflict of interests, due to a specific regulation of lobby (in the UK). It is a fact that in most cases ministers and also other high public representatives (officials) turn to specialized advisers to help them shape the regulation. These specialised advisers are often selected from industrial sectors. Actually, there has been a shift in the role of lobbyist from old-school lobbying to counselling. In this case, it is the same thing and most often a selected form of corporate lobbying ${ }^{46}$.

Legislators and policy-makers have limited time to listen to different lobby groups. Because of this, they introduce access charges in order to screen lobbyist. In other words, the more you pay, the more they listen to you. This makes a big difference between corporate and ENGOs lobbying, because usually the industry sector has more resources and staff for lobbying than the non-profit or non-governmental sector. Grossman and Helpman ${ }^{47}$ showed that when lobbying is costless, there are less biased groups that are willing to pay more for the opportunity to influence. ${ }^{48}$

Oil and energy companies have important impacts on the environment.It has been proven that these companies lobby the most after environmental disasters. One of the most famous cases happened in 2010, when the explosion of Deepwater Horizon drilling rig (in the Mexican Bay) was followed by a massive oil spill ${ }^{49}$.

Another important difference between corporate and non-corporate lobbying activities is that firms can choose their activities based only on the expected profit of achieving their lobbying target. Many other organizations have to lobby on the fields where their efforts are most likely to have the greatest policy or other effect ${ }^{50}$.

\section{Conclusion}

Environmental lobbying is often an efficient way of influencing the decision making process. Measuring interest groups and lobbying effectiveness has been sometimes avoided due to the difficulty of defining the concept. The institutional structure (e.g., Lithuania has a special environment due to historical reasons, post-Soviet republic, etc.,and different nature of environmental lobbying) and characteristics of the issue, interest groups and their strategies have to be considered.

46 Marusca, L.; Irimies, C., supra note 1.

47 Grossman, G.; Helpman, E., supra note 33.

48 Baron, D. 2002. Review of Grossman and Helpman's Special Interest Politics. Journal of Economic Literature. XL: 1221-1229.

49 Osofsky, H. M., et. al. 2012. Environmental Justice and the BP Deepwater Horizon Oil Spill. New York University Environmental Law Journal. 20(1): 1-81.

50 Godwin, K.; Lopez, E.; Seldon, B. 2008. Allocating Lobbying Resources between Collective and Private Rents. Political Research Quarterly.61(2): 345-359. 
Moreover, the results should be interpreted bearing in mind the aim of the paper, which is to examine the main factors and determinants that influence legal environmental regulations a consequence of lobbying in Lithuania and the UK. Having in mind the limitations about coincidently objectives compliance in policies, this paper can still help to determine which groups were successful to exert their opinions into the proposal or outcome by lobbyism. ENGOs lobbying is effective when they mobilize public pressure in cooperation with the media. Influence for ENGOs within the legislative process depends on their strategies, policies, their representatives personal capabilities and timing of their activities. With other forms of (informal) lobbying, success is dependent on clearness of their messages, favourable media coverage, peacefulness of protests and attendances. This happened in Lithuania when there were protests about Šilutè-Taurage Chevron shale gas fracking. ENGOs and local interest groups lobbying was effective, they reached an obligatory legal demand for local consent about the project, which was also one of the reasons for Chevron's retreat. Another example is Visaginas Nuclear Power Plant, where the lobby opposition successfully mobilized public participation, encouraged discourse and reflected in turn down on a referendum. Corporate environmental lobbying reflects the amount of interest some company has in the specific set of issues at a specific time. Nevertheless, there is always a question of financing on the table. In the UK case, due to special lobbying regulation, business representatives often cooperate with public officials as counsellors. Due to this, they can gain a bigger amount of influence inside the legislative process. Generally, most of the lobbying companies are from the oil or energy sector, e.g., the analysed Cuadrilla case. In Lithuania, there are two main processes that affect environmental lobbying: Europeanization and a parallel institutionalization. In the future, lobbying in the field of environment and climate change will be even more important. Many businesses are becoming greener and their priorities are becoming shifted. ENGOs are traditionally striving for the public (environmental) good. The combination of both sectors, together with information exchange and good support from the government, should lead to the sustainable development and environmentally friendly future.

\section{References}

A Guide to Effective Lobbying in Europe. The View of Policy-Makers. Edition 2013 [interactive]. New York City: Burson Marsteller, 2013 [accessed on 2013-10-29]. <http://lobbyingsurvey. burson-marsteller.eu/>.

A Guide to Effective Lobbying in Europe 2009 [interactive]. New York City:
Burson Marsteller, 2009 [accessed on 2013-08-27]. <http://www.bursonmarsteller.com/bm-blog/bursonmarstellers-guide-to-effectivelobbying-in-europe-2009/>.

Baron, D. 2002. Review of Grossman and Helpman's Special Interest Politics. Journal of Economic Literature. XL: 1221-1229. 
Aidt, T. S. 1998. Political internalization of economic externalities and environmental policy. Journal of Public Economics, 69: 1-16.

Binder, S.; Neumayer, E. 2005. Environmental Pressure Group Strength and Air Pollution: An Empirical Analysis. Ecological Economies. 55(4): 527-538.

Bradley, B. Lithuania Considers Revising Shale-Gas Laws After Chevron Quits[interactive]. New York City: Bloomberg, 2013 [accessed on 201401-28].<http://www.bloomberg.com/ news/2013-10-09/lithuania-considersrevising-shale-gas-laws-after-chevronquits.html>.

Fredriksson, Per G., et al. 2005. Environmentalism, Democracy and Pollution Control. Journal of Environmental Economics and Management. 49(2): 343-365.

Garçon, G. 2013. The Rights of Access to Justice in Environmental Matters in the EU - The Third Pillar of the Aarhus Convention. European Food \& Feed Law Review. 8(2): 78-90.

Gkotsis, I. I., et al. 2006. Lobbying for the Environment: The Case of Greenpeace. International Conference on Sustainable Management and Development of Mountainous and Island Areas. Naxos: University of Thrace, p. 114-121.

Godwin, K.; Lopez, E.; Seldon, B. 2008. Allocating Lobbying Resources between Collective and Private Rents. Political Research Quarterly.61(2): 345-359.

Grossman, G.; Helpman, E. 2001. Special Interest Politics. Cambridge: MIT Press.

Harvey, F.; Vaughan, A. Cuadrilla Announces Two New Lancashire Fracking Sites[interactive]. London: The Guardian, 2014 [accessed on 201402-11]. <http://www.theguardian.com/ environment/2014/feb/04/cuadrilla- two-new-lancashire-fracking-sitesshale-gas $>$.

Hodder, P. 2009-2010. Lobby Groups and Front Groups: Industry Tactics in the Climate Change Debate. Melbourne Journal of Politics. 34: 45-81.

Jaatinen, M. 1998. Lobbying for Conflict Accommodation - AContingency Model. Corporate Communications: An International Journal. 3(1): 23-42.

Jowit, J.; Gersmann, H. Fracking 'Probable'Cause of Lancashire Quakes [interactive]. London: The Guardian, 2011 [accessed on 2014-02-04]. <http://www.theguardian.com/ environment/2011/nov/02/frackingcause-lancashire-quakes $>$.

Kalniņš, V. 2011. Transparency in Lobbying: Comparative Review of Existing and Emerging Regulatory Regimes. Riga: Providus.

Lobbying [interactive]. London: The Parliament of the United Kingdom of Great Britain and Northern Ireland, 2013 [accessed on 2013-08-25]. <http:// www.parliament.uk/get-involved/ have-your-say/lobbying/>.

Lockwood, M. 2013. The Political Sustainability of Climate Policy: The Case of the UK Climate Change Act. Global Environmental Change. 23(5): 1339-1348.

Marusca, L.; Irimies, C. 2013. Models of Lobby in Europe. Journal of Media Research. 1(15): 56-62.

Mazylyte, L.; Povilaitis, R. 2011. Interest Representation at the European Union Level: The Case of Lithuanian Environmental Interest Groups. 7th Annual International Scientific Conference: New Dimensions in the Development of Society. Jelgava: Latvia University of Agriculture, p. 50-56.

Oates, W. E.; Portney, P. R. The Political Economy of Environmental Policy. 2003. Handbook of Environmental 
Economics. Amsterdam: Elsevier, p. 325-354.

Ono, T. 2009. The Political Economy of Environmental and Social Security Policies: The Role of Environmental Lobbying. Economics of Governance. 10(3): 261-296.

Osofsky, H. M., et. al. 2012. Environmental Justice and the BP Deepwater Horizon Oil Spill. New York University Environmental Law Journal. 20(1): 1-81.

Pocius, E. Chevron in Lithuania: The Environmental Perspective [interactive]. The Lithuania Tribune, 2012 [accessed on 2014-01-22]. <http://www. lithuaniatribune.com/18441/ chevronin-lithuania-the-environmentalperspective-201218441/>.

Reid, C. T. 2013. Climate Law in the United Kingdom. Jus Gentium: Comparative Perspectives on Law and Justice. Dordrecht: Springer, p. 537-549.

Rietig, K. Public Pressure versus Lobbying - How Do Environmental NGOs Matter Most in Climate Negotiations? Centre for Climate Change Economics and Policy, Working Paper No. 79. Grantham Research Institute on Climate Change and the Environment, Working Paper No. 70 [interactive]. London, Leeds: Centre for Climate Change Economics and
Policy; London: Grantham Research Institute on Climate Change and the Environment, 2011 [accessed on 2013-08-25]. <http://www2.lse.ac.uk/ GranthamInstitute/ publications/ WorkingPapers/Papers/70-79/WP70_ environmental-NGOS-climate.pdf $>$.

Rucht, D. 2001. Lobbying or Protest Strategies to Influence EU Environmental Policies. Contentious Europeans: Protest and Politics in an Integrating Europe. Lanham: Rowman\& Littlefield, p. 125-142.

Smith, G.; Connelly, J. 1999. Politics and the Environment. From Theory to Practice. London: Routledge.

Stigler, G.J. 1971. The Theory of Economic Regulation. Bell Journal of Economics and Management Science. 2(1): 3-21.

Thomas, C. Nongovernmental Organizations as a Lobbying Force in the European Union: Myths and Realities [interactive]. Juneau: University of Alaska, 1999 [accessed on 2013-08-25]. $<$ http://aei.pitt.edu/2402/1/002903_1. $\mathrm{PDF}>$.

Visaginas Nuclear Power Plant Project [interactive]. Vilnius: Lietuvosenergija, UAB, 2014 [accessed on 2014-01-24]. <http://www.vae.lt/en/pages/aboutthe-project $>$.

\title{
APLINKOSAUGINIO LOBIZMO EFEKTYVUMAS - LIETUVOS IR JUNGTINĖS KARALYSTĖS ATVEJŲ NAGRINĖJIMAS
}

\author{
Luka Vavtar \\ Liublianos universitetas, Slovėnija
}

Santrauka. Pastaraisiais dešimtmečiais daug demesio skiriama svarbiems, greitiems ir globaliems klimato pokyčiams ir aplinkosaugai. Dél šios priežasties šalys keičia savo teisés dokumentus, reglamentuojančius su klimato kaita susijusius klausimus. Tai sukelia socialine itampa ir dèl to yra bütina ịtraukti ịvairias lobistines grupes. Lietuvos aplinkosaugos grupes yra veikiamos europeizavimo grupiu bei ivairiu instituciniu 
procesų. Lietuva jau yra priemusị Lobistinès veiklos įstatyma ir šiuo požiūriu yra viena iš pirmaujančių Europoje. Jungtinè Karalystė $2008 \mathrm{~m}$. prièmé Klimato kaitos istatyma, nes to reikalavo skirtingos interesu grupes, ypač aplinkosaugos NVO ir ivairios korporacijos. Šio straipsnio tikslas yra išnagrinèti pagrindinius veiksnius, nulemiančius aplinkosaugos teisès dokumenty pakeitimus dèl lobistinès veiklos tiek Lietuvoje, tiek Jungtineje Karalystejje. Darbe parodyti lobizmo rezultatai įvairių sprendimų priemimo procesuose.

Reikšminiai žodžiai: aplinkosauginis lobizmas, europeizacija, instituciniai procesai, teisinis reguliavimas, Lietuva, Jungtine Karalyste.

Luka Vavtar, Liublianos universiteto Administravimo fakultetas. Mokslinių tyrimų kryptys: aplinkosaugos politika ir jos taikymas, aplinkos apsauga ir administravimo procedūros, aplinkosaugos ir socialinių aspektų samprata.

Luka Vavtar, University of Ljubljana, Faculty of Administration. Research interest: environmental policies and their application, environmental protection and administrative procedures, (public) perception of environmental and socioeconomic issues 